\title{
An Empirical Study on Human Resource Management Practices With Reference To Job Satisfaction at Hyderabad.
}

\author{
Mr. Uvais. M \\ Assistant Professor, Department of Business Administration, Aligarh Muslim University Centre, Malappuram, \\ India
}

\begin{abstract}
The employee Job satisfaction represents one of the most complex areas facing today's managers when it comes to managing their Employees. It is the most important area which must be given maximum concentration by the organization. Unless and until each and every organization spares no effort to find out the particular problems which affect not only their satisfaction but the entire performance, it will make oodles of disturbance. The particular study about the Human Resource Management Practices with special reference to job satisfaction gets relevance on this corner.

The study was conducted at Doctus Pvt Ltd at Hyderabad. The employee of the organization was the targeted population used for the study. The pilot study itself offered a lot of benefits to understand the situation and to finalize the samples of the study. The sample frame for study was 395; for conducting a pilot study, the researcher took a proportion of 5\% of sample frame, i.e. a size of 20. It showed the response as $95 \%$ belongs to a specific category. So the researcher have taken $P$ as $95 \%$ and $Q$ as $5 \%$.The level of confidence taken is $95 \%$, so the $Z$ value is 1.96.If $Z$ is $95 \%$ the $E$ value should be 5\%., Thus the sample size is 103.The Descriptive research was the methodology used in this study and stratified random sampling based on six departments as $H R$, Finance, Labor, Quality management, Production and $R \& D$ for selecting samples.

Finally, it was found that almost every employee were satisfied with their work under the given Human Resource Practices. The particular study again proved that the HRM practices have great much role inside the organization to meet their goals and targets. Until the organization giving full effort; each and every one should face disastrous results.
\end{abstract}

Keywords: Job satisfaction, Human Resource Management Practices

\section{Introduction}

The new millennium is not just a new beginning; it is a continuation of trends in human resource that have been following cyclical patterns throughout our country's history. In such a situation, the human resource must be seen as per its importance and it must be given all needed facilities then only each and every organization can reach its goals. Though the innovative things are happening, this particular resource must be given appropriate to cope up with the changes and alternatives as well as to overcome the challenges

Every organization has their own vision, mission, goals and objectives, and all these goals and objectives are achieved through the effective utilization of the most important resources i.e., the Human Resources. So human resources are considered as assets of the organization. Their happiness and satisfaction is very important for the success of an organization.

The value of any company at any economy is its people. Without human resource, nothing is complete in the world scenario. Human resource is the most important resource in any organization. To succeed, a business needs committed staffs to meet its aim and goals in determined tenures. Staff must be trained and motivated up to their needs and wants by the management to achieve their potential. It is the responsibility of the human resource department to ensure the recruits to correct staffs and they get appropriate training to ensure that the business meets its aim. The primary functions of Human resource department are to provide a professional service it enables the organization and employee to meet the overall objectives. By such kind of activity, it can be provide the services like recruitment and selection, promotions, discipline and grievance handlings, contract of employment, terms and conditions of services, health and safety, induction training and development, advice to management and staff on personal issues, probation reports, absence records, increments, statically reporting, employee relations, performance management, job evaluation, policy formulation to understand the best practices, retirements, occupational and career guidance redundancy advice, resignations, termination of employment. These are the functions as well as HR practices of Human Resource Departments. Earlier considered a support function for any business, HRM today is required to take in a more strategic role in order to align itself with the organization's business strategies. Hence, the HR manager is expected to take in the mantle of a business partner along with the managers of other line functions, in driving the firm's strategies 
The HRM practices has vital role to play to add the employee satisfaction and it would be depend on its adaptability. By providing all facilities, the employers get stable work force and the workers take active interest in their jobs and work with a feeling of involvement and participation. An effective and efficient HRM practices increase the productivity of organization and also promote healthy industrial relations and thereby the organization maintains industrial peace. Everything that managers do to recruit, select, train, communicate with, evaluate, and terminate employees is included in HRM (Dessler, 2003). Human resource management includes practices that managers use to organize, structure, and monitor production processes so that employees can more fully understand the process and the impact of their work on results. Developing human capital through continuing training may increase the productive output from each employee either through improvement in skill level or through improvement in morale and job satisfaction The social evils prevalent among the labors such as substance abuse etc. are reduced to a greater extent by the in time decisions.

Employee satisfaction has always been important issues for every organization.After all, high levels of absenteeism and staff turnover can affect your bottom line, as temps, all human resource management practices especially recruitment and retraining take their toll. But few practices (in fact, few organizations) have made job satisfaction a top priority, perhaps because they have failed to understand the significant opportunity that lies in front of them. Satisfied employees tend to be more productive, creative and committed to their employers, and recent studies have shown a direct correlation between staff satisfaction and related result satisfaction. ${ }^{1}$ Family business men who can create work environments that attract, motivate and retain hard-working individuals will be better positioned to succeed in a competitive environment that demands quality and cost-efficiency. What's more, all mangers or directors may even discover that by creating a positive workplace for their employees, they've increased their own job satisfaction as well.

\section{Objectives Of The Study}

The objectives of the study mainly ponder to understand that, whether the job satisfaction is dependent or independent on HRM practices. The study try to focus upon various HRM practices provided by Doctus.Pvt Ltd and to understand the satisfaction to its employees through it. The researcher spare no effort to find out whether the employees are satisfied with the existing HRM practices and working condition which are the attributes of satisfaction and to find out the response of employees' to the given HRM practices. The particular study also tries its level best to list out the problems of existing HRM practices system prevailing in the organization and to sugges whether any improvements are needed for the existing HRM practices which will endorse management and employee relationship.

\subsection{Job satisfaction}

\section{Literature Review}

Describes how content an individual is with his or her job. The happier people are within their job, the more satisfied they are said to be. Job satisfaction is not the same as motivation, although it is clearly linked. Job design aims to enhance job satisfaction and performance; methods include job rotation, job enlargement and job enrichment. Other influences on satisfaction include the management style and culture, employee involvement, empowerment and autonomous work groups. Job satisfaction is a very important attribute which is frequently measured by organizations. The most common way of measurement is the use of rating scales where employees report their reactions to their jobs.

One of the biggest preludes to the study of job satisfaction was the Hawthorne studies. These studies (1924-1933), primarily credited to Elton Mayo of the Harvard Business School, sought to find the effects of various conditions (most notably illumination) on workers' productivity. These studies ultimately showed that novel changes in work conditions temporarily increase productivity (called the Hawthorne Effect). It was later found that this increase resulted, not from the new conditions, but from the knowledge of being observed. This finding provided strong evidence that people work for purposes other than pay, which paved the way for researchers to investigate other factors in job satisfaction. Scientific management (Taylorism) also had a significant impact on the study of job satisfaction. Frederick Winslow Taylor's 1911 book, Principles of Scientific Management, argued that there was a single best way to perform any given work task. This book contributed to a change in industrial production philosophies, causing a shift from skilled labor and piecework towards the more modern approach of assembly lines and hourly wages. The initial use of scientific management by industries greatly increased productivity because workers were forced to work at a faster pace. However, workers became exhausted and dissatisfied, thus leaving researchers with new questions to answer regarding job satisfaction. It should also be noted that the work of W.L. Bryan, Walter Dill Scott, and Hugo Munsterberg set the tone for Taylor's work. 


\subsection{Models of job satisfaction}

\subsubsection{Affect Theory}

Edwin A. Locke's Range of Affect Theory (1976) is arguably the most famous job satisfaction model. The main premise of this theory is that satisfaction is determined by a discrepancy between what one wants in a job and what one has in a job. Further, the theory states that how much one values a given facet of work (e.g. the degree of autonomy in a position) moderates how satisfied/dissatisfied one becomes when expectations are/aren't met. When a person values a particular facet of a job, his satisfaction is more greatly impacted both positively (when expectations are met) and negatively (when expectations are not met), compared to one who doesn't value that facet. To illustrate, if Employee A values autonomy in the workplace and Employee B is indifferent about autonomy, then Employee A would be more satisfied in a position that offers a high degree of autonomy and less satisfied in a position with little or no autonomy compared to Employee B. This theory also states that too much of a particular facet will produce stronger feelings of dissatisfaction the more a worker values that facet.

\subsubsection{Dispositional Theory}

Another well-known job satisfaction theory is the Dispositional Theory It is a very general theory that suggests that people have innate dispositions that cause them to have tendencies toward a certain level of satisfaction, regardless of one's job. This approach became a notable explanation of job satisfaction in light of evidence that job satisfaction tends to be stable over time and across careers and jobs. Research also indicates that identical twins have similar levels of job satisfaction.

A significant model that narrowed the scope of the Dispositional Theory was the Core Self-evaluations Model, proposed by Timothy A. Judge in 1998. Judge argued that there are four Core Self-evaluations that determine one's disposition towards job satisfaction: self-esteem, general self-efficacy, locus of control, and neuroticism. This model states that higher levels of self-esteem (the value one places on his/her self) and general self-efficacy (the belief in one's own competence) lead to higher work satisfaction. Having an internal locus of control (believing one has control over herlhis own life, as opposed to outside forces having control) leads to higher job satisfaction. Finally, lower levels of neuroticism lead to higher job satisfaction

\subsubsection{Two-Factor Theory (Motivator-Hygiene Theory)}

Frederick Herzberg's two factor theory (also known as Motivator Hygiene Theory) attempts to explain satisfaction and motivation in the workplace This theory states that satisfaction and dissatisfaction are driven by different factors - motivation and hygiene factors, respectively. An employee's motivation to work is continually related to job satisfaction of a subordinate. Motivation can be seen as an inner force that drives individuals to attain personal and organization goals (Hoskinson, Porter, \& Wrench, p.133). Motivating factors are those aspects of the job that make people want to perform, and provide people with satisfaction, for example achievement in work, recognition, promotion opportunities. These motivating factors are considered to be intrinsic to the job, or the work carried out.Hygiene factors include aspects of the working environment such as pay, company policies, supervisory practices, and other working conditions.

While Hertzberg's model has stimulated much research, researchers have been unable to reliably empirically prove the model, with Hackman \& Oldham suggesting that Hertzberg's original formulation of the model may have been a methodological artifact. Furthermore, the theory does not consider individual differences, conversely predicting all employees will react in an identical manner to changes in motivating/hygiene factors. Finally, the model has been criticised in that it does not specify how motivating/hygiene factors are to be measured.

\subsection{Human resource Practices}

Human resource management is much discussed subject in today's world especially in business field. In a world where people's competencies and skill sets are described in paragraphs rather than in a few word and where media reports of salaries makes us do a double - take to ensure that seeing indeed believes, it is becoming increasingly challenging to manage this high potential we consider as the country's asset. Human resource management processes are those concerned with the development of HR practices followed by the strategic activities and policies that affect all the aspects of HR and employment management.

Our past two decades, the world saw a complete makeover in the way Human resource management in the organization was defined, but in India, the changes has been more prominent in the last decade or so, after liberalization. Today, managing the expectations and motivations of a skilled workforce had brought with it attend complexities in terms of the need for robust HR practices and organizational procedures. The shift in focus from traditional HRM to strategies HRM was inevitable. Competitive advantage for the organization lies not just in differentiating a product or service or in becoming the low cost leader but in also being able to tap the company's special skills or core competencies and rapidly respond to customer's needs and competitor's moves. 
HR management can play a role in identifying and analyzing external opportunities and threats that may be crucial to the company's success. It is in a unique position to supply competitive intelligence that may be useful in the strategic planning process.

Technical HRM practices spans a series of HR practices. The activities range from attracting high quality employees, placing them in appropriate position, training them to work in the firm's specific way, and motivating them to devote more enterprise effectiveness is likely to be decreased of not enough attention is paid to coordinating these separate HRM practices. For example, an excellent employee might find it quite difficult to achieve high performance without good training compatible with organizational goals and the work itself. Similarly, a lack of motivation for well trained employees may be linked with them performing below their potential. It logically follows that adoption of effective technical HRM activities is a key to implementing a set of internally consistent HR practices. In other words, effective technical HR activities are necessary for accomplishing the partial goal of HRM. The major HR practices followed in the organizations are follows.

\section{Recruitment} organization.

It is the process of searching the prospective employees and stimulating them to apply for jobs in the

\section{Selection}

Involves, hiring or picking for placement on jobs, a subset of workers from the total set of workers available for hire or placement on jobs. It is the process of picking the right candidate from a pool of candidates.

\section{Job description}

Job descriptions are lists of the general tasks, or functions, and responsibilities of a position. Typically, they also include to whom the position reports, specifications such as the qualifications needed by the person in the job, salary range for the position, etc. Job descriptions are usually developed by conducting a job analysis, which includes examining the tasks and sequences of tasks necessary to perform the job. The analysis looks at the areas of knowledge and skills needed by the job. Note that a role is the set of responsibilities or expected results associated with a job. A job usually includes several roles.

\section{Training and development}

Training is an organized procedure for increasing the knowledge and skill of people for a specific purpose. The trainees acquire new skill, technical knowledge, problem-solving ability, etc. It also gives an awareness of the rules and procedures to guide their behavior. Training improves the performance of employees on present jobs and prepares them for taking up new assignments in future. According to Edwin B. Flippo. "Training is the act of increasing the knowledge and skill of an employee for doing a particular job"

\section{On the job training:}

This is one of the commonly used type of training. It is also an effective method of training the operative personnel. In this method the worker is trained on the job and at his work-place.

\section{Off-the-job-training:}

This types of training can be given in a number of ways. Off-the-job-training consist of lectures, conferences, group discussion, case studies, and programmers instructions, etc. This method is generally used by government and public enterprises.

\section{Vestibule Training}

The terms vestibule training is used to impart training in a class room in the plant. When large number of workers is to be given training, then a separate training department is set up. The instructors impart on-the job training to new workers.

\section{Induction and placement}

Induction is a planned introduction of employees to their jobs, their co-workers and the organization.

\section{Career planning}

According to Douglas t. hall a career is "an individually perceived sequence of attitudes and behaviors associated with work related experiences and activities over the span of the person's life". 


\section{Performance appraisal}

Is the systematic evaluation of individuals with respect to their performance on the job \& their potential for development?

\section{Grievance handling}

Grievance "Any dissatisfaction or feeling of injustice in connection with one's employment situation that is brought to the notice of the management"

\section{Welfare activities}

Welfare means faring or doing well. It is a comprehensive term, and refers to the physical, mental, moral and emotional well-being of an individual. Further, the term welfare is a relative concept, relative in time and space. It therefore, varies from time to time, from region to region and from country.

\section{Quality of work life}

Quality of work life denotes all the organizational input which aims at the employee's satisfaction and enhancing organizational effectiveness. Richard Ewalton explains quality of work life in terms of eight broad conditions of employment that constitute desirable quality of work life. He proposed the same criteria for measuring QWL. Those conditions criteria include

\section{Incentives}

Incentive is monetary benefit paid to workmen in recognition of their outstanding performance.

\subsection{Job description}

\section{Data Analysis And Interpretation}

\begin{tabular}{|l|c|c|}
\hline Opinion & No. of respondents & $\begin{array}{l}\% . \text { of } \\
\text { Respondents }\end{array}$ \\
\hline Strongly agree & 19 & $18 \%$ \\
\hline Agree & 74 & $72 \%$ \\
\hline Neutral & 5 & $5 \%$ \\
\hline Somewhat disagree & 2 & $2 \%$ \\
\hline Strongly Disagree & 3 & $3 \%$ \\
\hline Total & $\mathbf{1 0 3}$ & $\mathbf{1 0 0 \%}$ \\
\hline
\end{tabular}

This table shows the samples' response about the job description in the organization. Amongst the 103 samples, $18 \%$ of them strongly agreed that it's good. $72 \%$ as agree, $5 \%$ as neutral, $2 \%$ as somewhat disagree and $3 \%$ has the opinion that, they are strongly disagree about the job description activity in the organization

\subsection{Health and safety}

\begin{tabular}{|l|c|c|}
\hline Opinion & No. of respondents & $\begin{array}{l}\text { \%.of } \\
\text { Respondents }\end{array}$ \\
\hline Strongly agree & 43 & $41 \%$ \\
\hline Agree & 40 & $39 \%$ \\
\hline Neutral & 6 & $6 \%$ \\
\hline Somewhat disagree & 7 & $7 \%$ \\
\hline Strongly Disagree & 7 & $7 \%$ \\
\hline Total & $\mathbf{1 0 3}$ & $\mathbf{1 0 0 \%}$ \\
\hline
\end{tabular}

This figure tells about the samples' response about health and safety in organization. Amongst the 103 samples, $41 \%$ of them strongly agreed in favor of it. $39 \%$ as agree, $6 \%$ as neutral, $7 \%$ as somewhat disagree and $7 \%$ has the opinion that, they are strongly disagree about the health and safety in the organization

\subsection{Performance Appraisal}

\begin{tabular}{|l|c|c|}
\hline Opinion & No. of respondents & $\%$.of Respondents \\
\hline Strongly agree & 33 & $32 \%$ \\
\hline Agree & 56 & $54 \%$ \\
\hline Neutral & 9 & $9 \%$ \\
\hline Somewhat disagree & 4 & $4 \%$ \\
\hline Strongly Disagree & 1 & $1 \%$ \\
\hline Total & $\mathbf{1 0 3}$ & $\mathbf{1 0 0 \%}$ \\
\hline
\end{tabular}


The above table shows that, out of the 103 samples, $32 \%$ of them strongly agreed the performance appraisal activity in the organization. 54\% agreed and $9 \%$ has a neutral opinion. $4 \%$ and $1 \%$ opinioned somewhat disagree and strongly disagree respectively

\subsection{Grievance Handling}

\begin{tabular}{|l|c|c|}
\hline Opinion & No. of respondents & $\%$.of Respondents \\
\hline Strongly agree & 11 & $11 \%$ \\
\hline Agree & 82 & $79 \%$ \\
\hline Neutral & 3 & $3 \%$ \\
\hline Somewhat disagree & 6 & $6 \%$ \\
\hline Strongly Disagree & 1 & $1 \%$ \\
\hline Total & $\mathbf{1 0 3}$ & $\mathbf{1 0 0 \%}$ \\
\hline
\end{tabular}

The above table shows that, out of the 103 samples, $11 \%$ of them strongly agreed with the existing grievance handling mechanism of the organization. 79\% agreed and 3\% has neutral opinion.6\% and 1\% opinioned somewhat disagree and strongly disagree respectively

\subsection{Welfare Activities}

\begin{tabular}{|l|c|c|}
\hline Opinion & No. of respondents & $\begin{array}{l}\% . \text { of } \\
\text { Respondents }\end{array}$ \\
\hline Strongly agree & 71 & $69 \%$ \\
\hline Agree & 22 & $21 \%$ \\
\hline Neutral & 1 & $1 \%$ \\
\hline Somewhat disagree & 4 & $4 \%$ \\
\hline Strongly Disagree & 5 & $5 \%$ \\
\hline Total & $\mathbf{1 0 3}$ & $\mathbf{1 0 0 \%}$ \\
\hline
\end{tabular}

The particular table tells about the samples' response about whether the organization provides enough welfare activities or not. Amongst the 103 samples, $69 \%$ of them strongly agreed in favor of it.21\% as agree, $1 \%$ as neutral, $4 \%$ as somewhat disagree and $5 \%$ has the opinion that, they are strongly disagree about the welfare activities provide by the organization

\subsection{Quality of work life}

\begin{tabular}{|l|c|c|}
\hline Opinion & No. of respondents & $\%$.of Respondents \\
\hline Strongly agree & 40 & $39 \%$ \\
\hline Agree & 32 & $31 \%$ \\
\hline Neutral & 6 & $6 \%$ \\
\hline Somewhat disagree & 19 & $18 \%$ \\
\hline Strongly Disagree & 6 & $6 \%$ \\
\hline Total & $\mathbf{1 0 3}$ & $\mathbf{1 0 0 \%}$ \\
\hline
\end{tabular}

The above table shows that, out of the 103 samples, $39 \%$ of them strongly agreed with the existing quality of work life in the organization. $31 \%$ agreed and $6 \%$ has a neutral opinion.18\% and $6 \%$ opinioned somewhat disagree and strongly disagree respectively

\subsection{Security}

\begin{tabular}{|l|c|c|}
\hline Opinion & No. of respondents & $\%$.of Respondents \\
\hline Strongly agree & 51 & $49 \%$ \\
\hline Agree & 38 & $37 \%$ \\
\hline Neutral & 3 & $3 \%$ \\
\hline Somewhat disagree & 9 & $9 \%$ \\
\hline Strongly Disagree & 2 & $2 \%$ \\
\hline Total & $\mathbf{1 0 3}$ & $\mathbf{1 0 0 \%}$ \\
\hline
\end{tabular}


When the samples were asked about the security they have in their work place, $49 \%$ strongly agreed that they have enough status in the particular job they do. 37\%agreed the question and 3\% denoted as neutral. 9\% showed as somewhat disagree and $2 \%$ indicated as strongly disagree

\section{FINDINGS}

Job satisfaction is dependent on Human Resource Management Practices. The employees were fully responsive to the particular study and their satisfaction is utterly influenced by the selection procedures prevailing in the organization. It shows that the training and development programs have a little influence in employee satisfaction and performance appraisal have a lot of influence in job satisfaction of employees.

One of the serious findings was job satisfaction has great independence on grievance handling mechanisms prevailing in the organization and employee satisfaction is majorly depended upon welfare activities. Incentives and supervisor's role have great influence on job satisfaction. They tell that satisfaction of employee is highly depended upon their salary and interpersonal relation in the company has great influence on job satisfaction. One of the important findings was availing growth opportunity has deep influence on employee satisfaction which reflected that $85 \%$ of the employees have keen interest in their job. Employee's job satisfaction is highly depended upon the security in their job also an outcome of the study.

It proclaim that company's policies have great influence in job satisfaction and Job satisfaction is strongly depended upon the communication path existing in the organization as it gives a great freedom of expression and working condition of the organization also helped the well.

\section{Conclusion}

The HRM practices has vital role to play to add the employee satisfaction and it would be depend on its adaptability. By providing all facilities, the employers get stable work force and the workers take active interest in their jobs and work with a feeling of involvement and participation. An effective and efficient HRM practices increase the productivity of organization and also promote healthy industrial relations and thereby the organization maintains industrial peace.

Today's concepts are entirely different with the past. Then people were sticking with any job they get to meet their ends. Though they get bad workforce and bad results, they were compelled to continue their works without having any irritation. But today, if the human resource gets no proper practices and circumstance, end of the day the organization can see the gap. All things are depended upon the manpower with the company. Unless and until organization spare no effort to make their manpower very satisfied one, they can't touch peaks but collapses.

Doctus softare solution Pvt. Ltd, Hyderabad, is one of the good companies providing sufficient human resource practices, so that they can see the benefits and results respectively. The company provides all needed practices to its employees and they are treated as on of the important assets of the organization and make them too feel like that. This study has impartial results on its findings so that it can be conclude that Human resource practices have great range of influence on the employee's job satisfaction.

\section{References}

[1] Armstrong Michael, Human Resource Management, New Delhi, Kogan Page India 2003, $9^{\text {th }}$ edition

[2] Aswhthappa, Human Resource and Personnal Management, New Delhi, Tata Mc Graw-Hill, $3^{\text {rd }}$ edition

[3] Bhattacharya Kumar Diapk, Human Resource Management, , New Delhi, Excel Books 2002, $1^{\text {ST }}$ edition

[4] Monoppa \& Saiyadain, Personnel Management, Tata McGraw Hill, New Delhi.

[5] Patnayak, Biswajeet, Human Resource Management, ed. iii, 2006, P.H., New Delhi

[6] Pramod Verma, Management of Industrial Relations, Vora Prakashan, Ahmedabad.

[7] Sinha, PRN, Sinha IB and Shekhar SP, Industrial Relations, Trade Unions and Labour

[8] Armstrong, M. (2006). A Handbook of Human resource Management Practice, Tenth Edition, Kogan Page Publishing, London.

[9] Arvey, R. D., Bouchard, T. J., Segal, N. L., \& Abraham, L. M. (1989). Job satisfaction: Environmental and genetic components. Journal of Applied Psychology, 74, 187-192 